\title{
PENERAPAN MODEL PEMBELAJARAN KOOPERATIF TIPE SNOWBALL THROWING UNTUK MENINGKATKAN HASIL BELAJAR IPS SISWA
}

\author{
Asrinah \\ asrinah-as@yahoo.com \\ SD Negeri 022 Pulau Baru Kopah, Kuantan Tengah, Indonesia
}

\begin{abstract}
This research is motivated by the low social studies learning outcomes of students. This study aims to improve student learning outcomes by applying snowball throwing learning models. Where with this application is able to train students' leadership spirit, train students to learn independently, foster student learning creativity. This research was conducted at SDN 022 Pulau Baru Kopah. The subjects of the study were the third grade students, which consisted of 20 students consisting of 10 men and 10 women. The type of this research was classroom action research with a collaborative form. While this class action research procedure consists of, planning, implementing, observing, and reflecting. The results showed, the initial data completeness of social studies learning outcomes of students only 11 people or 55\% of students who completed while 9 students or $45 \%$ did not complete. the first cycle by applying the snowball throwing cooperative learning model, student learning outcomes improved. This can be seen from 20 students, as many as 15 or $75 \%$ of students have been completed while 5 students or $25 \%$ of students have not been completed. In cycle II student learning outcomes increased again, this can be seen from the number of students who completed as many as 18 students or $90 \%$ while students who have not finished reduced to 2 students or 10\%. The researcher can conclude that by applying the snowball throwing cooperative learning model can improve the social learning outcomes of students of SDN 022 Pulau Baruh Kopah
\end{abstract}

Keywords: cooperative learning model snowball throwing type, social studies learning outcomes

\section{ABSTRAK}

Penelitian ini dilatarbelakangi oleh hasil belajar IPS siswa yang masih rendah. Penelitian ini bertujuan meningkatkan hasil belajar siswa dengan menerapkan model pembelajaran snowball throwing. Dimana dengan penerapan ini mampu melatih jiwa kepemimpinan siswa, melatih siswa untuk belajar mandiri, menumbuhkan kreativitas belajar siswa. Penelitian ini dilaksanakan di SD Negeri 022 Pulau Baru Kopah. Subjek penelitian adalah siswa kelas III yang berjumlah 20 siswa terdiri dari laki-laki 10 dan perempuan 10. Jenis penelitian ini adalah penelitian tindakan kelas (PTK) dengan bentuk kolaboratif. Sedangkan prosedur penelitian tindakan kelas ini terdiri atas, perencanaan, pelaksanaan, pengamatan, dan refleksi. Hasil penelitian menunjukan, data awal ketuntasan hasil belajar IPS siswa hanya 11 orang atau 55\% siswa yang tuntas sedangkan 9 orang siswa atau $45 \%$ tidak tuntas. siklus I dengan menerapkan model pembelajaran kooperatif tipe snowball throwing, hasil belajar siswa meningkat. Hal ini terlihat dari 20 orang siswa, sebanyak 15 atau $75 \%$ siswa telah tuntas sedangkan 5 orang siswa atau $25 \%$ siswa belum tuntas. Pada siklus II hasil belajar siswa kembali meningkat, hal ini terlihat dari jumlah siswa yang tuntas sebanyak 18 orang siswa atau 90\% sedangkan siswa yang belum tuntas berkurang menjadi 2 orang siswa atau 10\%. Dapat peneliti simpulkan bahwa dengan menerapkan model pembelajaran kooperatif tipe snowball throwing dapat meningkatkan hasil belajar IPS siswa SD Negeri 022 Pulau Baruh Kopah.

Kata Kunci: model pembelajaran kooperatif tipe snowball throwing, hasil belajar IPS

\begin{tabular}{|c|c|c|}
\hline Submitted & Accepted & Published \\
\hline 10 Juli 2019 & 04 November 2019 & 13 November 2019 \\
\hline
\end{tabular}

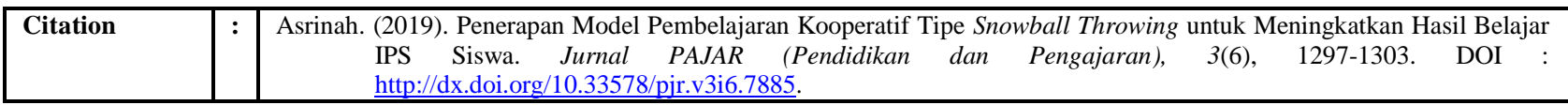

\section{PENDAHULUAN}

Kualitas pendidikan yang baik dapat ditempuh melalui pendidikan formal, nonformal, maupun informal. Semua jalur yang digunakan dalam pendidikan sama-sama memiliki maksud dan tujuan yang sama, yaitu mengembangkan potensi siswa dalam meningkatkan dan menumbuh kembangkan kualitas sumber daya manusia (SDM). Pendidikan formal khususnya di
Indonesia diawali dari tingkat sekolah dasar (SD). Proses pembelajaran di sekolah dasar, siswa diajarkan berbagai macam mata pelajaran wajib, yaitu: Bahasa Indonesia, Matematika, IPS, IPA, PKn, Pendidikan Jasmani dan Kesehatan, serta Pendidikan Agama.

Ilmu pengetahuan sosial (IPS) adalah salah satu mata pelajaran yang wajib dipelajari di 
sekolah dasar. Menurut Samlawi dan Maftuh (dalam Kurniyati, 2016) IPS merupakan mata pelajaran yang memadukan konsep-konsep dasar dari berbagai ilmu sosial seperti ilmu sejarah, sosiologi, ilmu politik dan ekonomi, serta geografi. Sehingga ilmu sosial yang dimaksud sangat berperan untuk mendukung mata pelajaran IPS dengan memberikan sumbangan berupa konsep-konsep ilmu sehingga berubah menjadi pengetahuan yang berkaitan erat dengan kehidupan sosial yang harus dipelajari siswa di sekolah dasar.

Pada dasarnya pembelajaran IPS sebenarnya tidaklah sulit untuk dipelajari. Namun, kenyataannya pada proses pembelajaran IPS, banyak sekali masalah muncul yang ditemui oleh peneliti sendiri sebagai guru kelas III di SD Negeri 022 Pulau Baru Kopah, diantaranya: kurangnya kemampuan siswa dalam memahami pelajaran, masih banyaknya anggapan siswa bahwa materi IPS adalah bersifat hafalan, sering sekali peneliti/ guru kesulitan dalam membangkitkan minat belajar siswa, dikarenakan tidak optimalnya guru dalam menerapkan metode pembelajaran yang ada, sering sekali guru kesulitan dalam memilih atau menentukan alat peraga yang sesuai dengan materi yang diajarkan, serta guru merasa kesulitan menanamkan konsep yang benar pada siswa.

Permasalahan dan kesulitan di dalam proses pembelajaran yang diuraikan di atas, menyebabkan hasil belajar siswa menjadi rendah. dari 20 siswa hanya 11 siswa atau 55\% yang tuntas, sedangkan 19 siswa atau 45\% masih belum tuntas. Siswa dikatakan tuntas apabila siswa telah mencapai nilai kriteria ketuntasan minimum (KKM) sekolah sebesar 70 .

Sejalan dengan penelitian yang dilakukan oleh Lestari (2014) mengungkapkan permasalahan dalam pembelajaran IPS antara lain adalah guru kurang terampil dalam memilih

\section{KAJIAN TEORETIS}

Menurut Sagala (2007) menyatakan model diartikan sebagai kerangka konseptual yang digunakan sebagai pedoman dalam melakukan kegiatan. Model dapat dipahami sebagai: (1) suatu tipe atau desain; (2) suatu deskripsi atau analogi permasalahan yang relevan untuk diajukan kepada kelas dan sesuai dengan daya nalar siswa, guru kurang terampil menumbuhkan motivasi belajar siswa dan menciptakan situasi belajar siswa yang menyenangkan, kurangnya fasilitas dan sumber belajar yang cukup. Lebih lanjut, Patimasang (2015) mengungkapkan bahwa faktor yang menyebabkan rendahnya pemahaman siswa terhadap materi pelajaran IPS di sekolah dasar disebabkan oleh kegiatan pembelajaran yang dilaksanakan selama ini menyebabkan siswa bertindak pasif menerima informasi. Dikarenakan di dalam proses pembelajaran guru lebih mendominasi tanpa memberikan kesempatan kepada siswa untuk mengkonstruksi sendiri pemahamannya. Selain itu, siswa kurang dilibatkan untuk mendiskusikan materi yang disajikan, akibatnya siswa tidak dapat mengembangkan kreativitas dan kemampuannya dalam proses pembelajaran. Selain itu penyebab utama dari masalah ini adalah selain disebabkan oleh ketidaktepatan metodologis (Intan, 2016).

Berdasarkan temuan permasalahan di atas, peneliti berusaha untuk meningkatkan hasil belajar IPS dengan menerapkan model pembelajaran kooperatif tipe snowball throwing. Alasan utama peneliti menerapkan model pembelajaran kooperatif tipe snowball throwing adalah untuk membantu mengefektifkan pembelajaran melalui diskusi, siswa belajar dengan kelompoknya dan berupaya bertukar ide, serta memperkuat rasa percaya diri siswa. selain itu, semua siswa mempunyai kesempatan berpartisipasi di kelas, siswa dapat mengembangkan kecakapan hidup sosial mereka, dan interaksi antar siswa cukup tinggi karena akan terlibat secara aktif dalam berbicara maupun mendengarkan. Sedangkan tujuan dalam penelitian ini adalah untuk meningkatkan hasil belajar IPS siswa dengan menerapkan model pembelajaran kooperatif tipe snowball throwing.

yang dipergunakan untuk membantu proses visualisasi sesuatu yang tidak dapat dengan langsung diamati; (3) suatu sistem asumsi-asumsi, data-data dan interferensi-interferensi yang dipakai untuk menggambarkan secara matematis 
suatu obyek atau peristiwa; (4) suatu desain yang disederhanakan dari suatu sistem kerja, suatu terjemahan realitas yang disederhanakan; (5) suatu deskripsi dari suatu sistem yang mungkin atau imajiner; dan (6) penyajian yang diperkecil agar dapat menjelaskan dan menunjukkan sifat bentuk aslinya. Sedangkan model pembelajaran adalah kerangka konseptual yang melukiskan prosedur yang sistematis dalam mengorganisasikan pengalaman belajar untuk mencapai tujuan belajar tertentu dan berfungsi sebagai pedoman bagi para perancang pembelajaran dan para pengajar dalam merencanakan aktivitas belajar mengajar Nurulwati (Trianto, 2007).

Menurut Kokom (2010) model pembelajaran kooperatif tipe snowball throwing merupakan model pembelajaran yang mengali potensi kepemimpinan siswa dalam kelompok dan keterampilan membuat jawaban pertanyaan yang dipadukan melalui suatu permainan imajinatif membentuk dan melempar bola salju. Sedangkan Istarani (2012) mengatakan bahwa model pembelajaran kooperatif tipe snowball throwing merupakan rangkaian penyajian materi ajar yang diawali dengan penyampaian materi lalu membentuk kelompok dan ketua kelompoknya yang kemudian masing-masing ketua kelompok kembali kekelompoknya masing-masing, kemudian menjelaskan materi yang disampaikan oleh guru kepada temannya serta dilanjutkan dengan masing-masing peserta didik diberi satu lembar kertas untuk menuliskan satu pertanyaan apa saja yang menyangkut materi yang sudah dijelaskan oleh ketua kelompok.

Langkah-langkah penerapan snowball throwing dalam pembelajaran menurut Suprijono (2011) adalah sebagai berikut: 1) Guru menyampaikan materi yang akan disajikan; 2) Guru membentuk kelompok-kelompok dan memanggil masing-masing ketua kelompok untuk memberikan penjelasan tentang materi; 3) Masing-masing ketua kelompok kembali ke kelompoknya masing-masing kemudian menjelaskan materi yang disampaikan oleh guru kepada temannya; 4) Masing-masing siswa diberikan satu lembar kertas kerja untuk menuliskan satu pertanyaan apa saja yang menyangkut materi yang sudah dijelaskan oleh ketua kelompok; 5) Kertas yang berisi pertanyaan tersebut dibuat seperti bola dan dilempar dari satu siswa ke siswa yang lain selama \pm 15 menit; 6) Setelah siswa dapat satu bola/satu pertanyaan diberikan kesempatan kepada siswa untuk menjawab pertanyaan yang tertulis dalam kertas yang berbentuk bola tersebut secara bergantian; 7) Evaluasi; dan 8) Penutup.

Ada pun kelebihan serta kelemahan dari model pembelajaran snowball throwing menurut Istarani (2012) adalah sebagai berikut:

1. Kelebihan model pembelajaran snowball throwing:

a) Meningkatkan jiwa kepemimpinan siswa, sebab ada ketua kelompok yang diberikan tugas kepada teman-temanya.

b) Melatih siswa untuk belajar mandiri, karena masing-masing siswa diberikan tugas untuk membuatkan satu pertanyaan, lalu pertanyaan itu akan dijawab oleh temannya atau sebaliknya.

c) Menumbuhkan kreativitas belajar siswa karena membuat bola sebagaimana yang diinginkannya.

d) Belajar lebih hidup, karena semua siswa aktif membuat pertanyaan ataupun menjawab soal temanya yang jatuh pada dirinya.

2. Kelemahan model pembelajaran kooperatif tipe snowball throwing:

a) Ketua kelompok sering sekali menyampaikan materi pada temanya tidak sesuai dengan apa yang disampaikan oleh guru kepadanya.

b) Sulit bagi siswa untuk menerima penjelasan dari teman atau ketua kelompoknya karena kurang jelas dalam menjelaskanya.

c) Sulit bagi siswa untuk membuat pertanyaan secara baik dan benar.

d) Sulit dipahami oleh siswa yang menerima pertanyaan yang kurang jelas arahnya sehingga merepotkannya dalam menjawab pertanyaan tersebut

e) Siswa kurang maksimal atau menghayati peran yang dilakoninya,

f) Sulit mengontrol pembelajaran tercapai atau tidak 


\section{METODE PENELITIAN}

Penelitian ini dilaksanakan di SD Negeri 022 Pulau Baru Kopah, Kecamatan Kuantan Tengah, Kabupaten Kuantan Singingi. Subjek penelitian ini adalah seluruh siswa kelas III SD Negeri 022 Pulau Baru Kopah yang berjumlah 20 orang siswa. Terdiri dari 10 siswa laki-laki dan 10 siswa perempuan.

Sesuai dengan masalah yang dikemukakan pada pendahuluan, maka jenis penelitian ini adalah penelitian tindakan kelas (PTK) dengan bentuk kolaboratif, penelitian ini adalah penelitian yang dilakukan oleh peneliti/guru didalam kelasnya sendiri dengan tujuan memperbaiki kinerjanya sebagai guru, sehingga hasil belajar siswa dapat meningkat. Tindakan yang dilakukan adalah penerapan model pembelajaran kooperatif tipe snowball throwing. Peneliti/ guru bersama-sama akan melakukan perencanaan tindakan dan refleksi hasil tindakan. Sedangkan prosedur penelitian tindakan kelas ini terdiri atas, perencanaan, pelaksanaan, pengamatan, dan refleksi.

1. Tahap Perencanaan

Pada tahap perencaan ini merupakan perencanaan awal yang harus dilaksanakan yaitu, menentukan materi yang akan disampaikan kepada siswa sehingga kegiatan menjadi lebih terarah. Adapun perangkat pembelajaran yang perlu disiapkan oleh peneliti adalah: Silabus, RPP, LKS, Lembar aktivitas siswa dan guru.

2. Tahap Pelaksanaan Tindakan

Tahap pelaksanaan pembelajaran harus sesuai dengan RPP yang telah disesuaikan dengan kegiatan pembelajaran dan aktivitas siswa selama kegiatan pembelajaran berlangsung dengan menerapkan model kooperatif tipe snowball throwing.

\section{Tahap Observasi}

Tahap observasi dilakukan bersamaan waktunya dengan pelaksanaan tindakan yaitu dalam proses pembelajaran dengan penerapan model kooperatif tipe snowball throwing yang dilaksanakan oleh guru dengan menggunakan lembar observasi.

4. Tahap Refleksi

Tahap ini meliputi kegiatan analisis hasil pembelajaran dan penyusunan rencana perbaikan pada pembelajaran yang berikutnya.

Teknik pengumpulan data pada penelitian tindakan kelas (PTK) yang dilakukan menggunakan teknik tes dan non tes. Teknik tes merupakan teknik yang dilakukan dalam bentuk tes hasil belajar IPS siswa, datanya diambil dari skor tes hasil belajar siswa. Sedangkan teknik non tes dilakukan dengan lembar pengamatan siswa yang telah tersedia, lembar pengamatan ini dilakukan dengan menceklis pada aktivitas guru dan aktivitas siswa.

Teknik analisis data diambil dari aktivitas guru dan siswa. Aktivitas guru dan siswa selama kegiatan pembelajaran berlangsung dianalisis dengan menggunakan rumus:

$\mathrm{P}=\frac{F}{N} \times 100 \%$

(dalam Sumarliani \& Suprayitno, 2018)

Keterangan:

$\mathrm{P} \quad=$ Persentase rata-rata aktivitas (guru dan Siswa)

$\mathrm{F} \quad=$ Jumlah Skor Aktivitas yang dilakukan

$\mathrm{N}=$ Skor maksimal yang didapat dari aktivitas guru/siswa

Tabel 1. Aktivitas Guru dan Siswa

\begin{tabular}{ll}
\hline Interval & Kategori \\
$81-100$ & Amat baik \\
$61-80$ & Baik \\
$51-60$ & Cukup \\
Kurang dari 50 & Kurang \\
\hline
\end{tabular}


Menurut Asnimar (2018) hasil belajar siswa dihitung dengan menggunakan rumus sebagai berikut:

$\mathrm{S}=\frac{R}{N} \times 100 \%$

\section{HASIL DAN PEMBAHASAN}

Data yang dianalisis dalam penelitian ini adalah data tentang aktivitas guru, aktivitas siswa dan hasil belajar siswa. Uraiannya dalam penelitian ini adalah sebagai berikut :

\section{Aktivitas Guru}

Aktivitas guru yang diamati dalam penelitian ini terdiri dari 4 pertemuan untuk 2 siklus. Berdasarkan hasil observasi yang dilakukan observer terhadap aktivitas guru dalam menerapkan model pembelajaran kooperatif tipe snowball throwing, maka diketahui hasil aktivitas guru dari siklus I sampai siklus II sebagai berikut:

\section{Aktivitas Guru Siklus I}

Pertemuan pertama siklus I diperoleh nilai aktivitas guru sebesar 20 dengan persentase 55\% kategori cukup. Rendahnya penilaian aktivitas guru pada pertemuan pertama di sebabkan guru kurang menguasai kelas, hal ini dapat dilihat sewaktu guru memotivasi siswa dan guru membagi kelompok terlihat siswa sangat ribut, dan tidak banyak pula siswa yang ingin membentuk kelompok sendiri. Sedangkan pada pertemuan kedua siklus I, aktivitas guru mendapat nilai sebesar 25 dengan persentase 69.4\% kategori baik. Pada pertemuan kedua ini, aktivitas guru sudah mulai membaik dari pada pertemuan pertama namun kekurangan guru pada pertemuan kedua ini guru masih kurang mengarahkan siswa dalam mengerjakan LKS, tetapi persentase aktivitas guru dari pertemuan pertama kepertemuan kedua meningkat.

\section{Aktivitas Guru Siklus II}

Pertemuan pertama siklus ke II, hasil penilaian aktivitas guru sebesar 29 dengan persentase sebesar $80.5 \%$ dengan kategori baik. Pada pertemuan ini sudah lebih meningkat, dibandingkan pada siklus I, peningkatan ini terjadi karena guru telah dapat menguasai kelas dan memotivasi siswa dengan baik. Untuk
Keterangan:

$$
\begin{array}{ll}
\mathrm{S} & =\text { Hasil Belajar } \\
\mathrm{R} & =\text { Jumlah Soal yang Dijawab Benar } \\
\mathrm{N} & =\text { Jumlah Soal }
\end{array}
$$

pertemuan kedua pada siklus II, diperoleh hasil penilaian aktivitas guru sebesar 31 dengan persentase sebesar $86.1 \%$ dengan kategori amat baik. Pertemuan kedua siklus II ini mengalami peningkatan lagi dari pertemuan sebelumnya dan berjalan dengan lancar.

\section{Aktivitas Siswa}

Data aktivitas siswa yang diperoleh selama proses pembelajaran menggunakan model pembelajaran kooperatif tipe snowball throwing, sama halnya dengan aktivitas guru. Pada aktivitas siswa juga terdiri dari 4 pertemuan. Setiap siklus terdiri dari 2 kali pertemuan. Data tersebut dapat diuraikan sebagai berikut:

\section{Aktivitas Siswa Siklus I}

Pertemuan pertama siklus I, aktivitas siswa mendapat nilai sebesar 19 dengan persentase sebesar $52.2 \%$ dengan kategori cukup. Pertemuan kedua siklus I, aktivitas siswa mendapat nilai sebesar 26 dengan persentase sebesar $72.2 \%$ kategori baik. Pada pertemuan siklus I ini siswa kurang serius dalam menerima pembelajaran, hal ini terlihat saat guru menyampaikan materi pembelajaran terlihat siswa masih banyak yang meribut. Selain itu, siswa dalam mengerjakan LKS masih ada yang mencontek temannya.

\section{Aktivitas Siswa Siklus II}

Pertemuan pertama siklus II, terlihat peningkatan dari pertemuan disiklus sebelumnya, pertemuan pertama siklus II aktivitas siswa mendapat nilai sebesar 30 dengan persentase sebesar $83.3 \%$ dengan kategori baik. Pada pertemuan kedua aktivitas siswa mendapat nilai sebesar 32 dengan persentase $86.1 \%$ kategori amat baik. Pada pertemuan ini peningkatan terjadi karena siswa sudah serius dalam mengikuti pembelajaran, tidak terlihat lagi 
siswa yang melakukan kegiatan lain dan keadaan kelas sangat kondusif.

\section{Hasil Belajar Siswa}

Peningkatan Hasil Belajar IPS Siswa Kelas III SD Negeri 022 Pulau Baru Kopah dapat dilihat bahwa sebelum diterapkan model pembelajaran kooperatif tipe snowball throwing ketuntasan hasil belajar IPS siswa hanya 11 orang atau 55\% siswa yang tuntas atau mencapai KKM yang telah ditentukan sekolah sedangkan 9 orang siswa atau $45 \%$ tidak tuntas atau mencapai nilai KKM. Setelah dilaksanakan siklus I dengan menerapkan model pembelajaran kooperatif tipe snowball throwing, hasil belajar siswa meningkat. Hal ini terlihat dari 20 orang siswa, sebanyak 15 atau $75 \%$ siswa telah tuntas atau telah mencapai nilai KKM. Sedangkan 5 orang siswa atau $25 \%$ siswa belum tuntas atau belum mencapai nilai KKM. Pada siklus II hasil belajar siswa kembali meningkat, hal ini terlihat dari jumlah siswa yang tuntas sebanyak 18 orang siswa atau 90\% sedangkan siswa yang belum tuntas berkurang menjadi 2 orang siswa atau 10\%. Hal ini menunjukkan bahwa model pembelajaran kooperatif tipe snowball throwing yang dilakukan oleh guru sudah mendapatkan nilai yang baik, terutama dalam proses mendengarkan, menulis pertanyaan dan membuat bola salju dari kertas. Sehingga hasil

\section{SIMPULAN DAN REKOMENDASI}

Berdasarkan hasil penelitian di atas dapat peneliti simpulkan bahwa dengan menerapkan model pembelajaran kooperatif tipe snowball throwing dapat meningkatkan hasil belajar IPS siswa SD Negeri 022 Pulau Baruh Kopah, Kecamatan Kuantan Tengah, Kabupaten Kuantan Singingi. Hal ini dibuktikan oleh:

1. Aktivitas Guru, pertemuan pertama siklus I diperoleh nilai aktivitas guru sebesar 20 dengan persentase 55\% kategori cukup. Sedangkan pada pertemuan kedua siklus I, aktivitas guru mendapat nilai sebesar 25 dengan persentase $69.4 \%$ kategori baik. Siklus ke II, hasil penilaian aktivitas guru pertemuan pertama sebesar 29 dengan persentase sebesar $80.5 \%$ dengan kategori baik. Untuk pertemuan belajar siswa meningkat dan siswa tuntas memperoleh nilai KKM yang ditetapkan oleh sekolah.

Hasil penelitian di atas sejalan dengan pendapat Yuliati (2015) yang mengungkapkan di dalam model snowball throwing, siswa diberi kesempatan oleh guru untuk dapat mengembangkan keterampilan menyimpulkan isi berita atau informasi yang mereka peroleh dalam konteks nyata dan situasi yang kompleks. Selain itu Gustomo dan Sudarman (2015) model pembelajaran snowball throwing dapat mengefektifkan kerjasama dan partisipasi antar siswa lain, hal ini dapat terlihat dengan jelas melalui kelompok-kelompok yang telah terbentuk sebelumnya, sehingga mereka dapat bertukar pikiran dengan baik antar sesama siswa lain, terutama dengan teman satu kelompok.

Pembelajaran IPS selayaknya dapat membekali siswa dengan pengetahuan dan ketrampilan intelektual yang memadai serta pengalaman praktis agar memiliki kompetensi. Oleh karena itu, ada dua hal yang perlu mendapat perhatian guru dalam mempersiapkan pembelajaran IPS di kelas, yakni bekal pengetahuan materi pembelajaran dan metode atau pendekatan pembelajaran, yang bertujuan untuk meningkatkan hasil belajar IPS siswa (Winataputra, dkk, 2012).

kedua pada siklus II, diperoleh hasil penilaian aktivitas guru sebesar 31 dengan persentase sebesar $86.1 \%$ dengan kategori amat baik.

2. Aktivitas Siswa, pertemuan pertama siklus I, aktivitas siswa mendapat nilai sebesar 19 dengan persentase sebesar $52.2 \%$ dengan kategori cukup. Pertemuan kedua siklus I, aktivitas siswa mendapat nilai sebesar 26 dengan persentase sebesar $72.2 \%$ kategori baik. Pertemuan pertama siklus II aktivitas siswa mendapat nilai sebesar 30 dengan persentase sebesar $83.3 \%$ dengan kategori baik. Pada pertemuan kedua aktivitas siswa mendapat nilai sebesar 32 dengan persentase $86.1 \%$ kategori amat baik.

3. Hasil Belajar, data awal ketuntasan hasil 
belajar IPS siswa hanya 11 orang atau 55\% siswa yang tuntas sedangkan 9 orang siswa atau $45 \%$ tidak tuntas. siklus I dengan menerapkan model pembelajaran kooperatif tipe snowball throwing, hasil belajar siswa meningkat. Hal ini terlihat dari 20 orang siswa, sebanyak 15 atau $75 \%$ siswa telah tuntas sedangkan 5 orang siswa atau $25 \%$ siswa belum tuntas. Pada siklus II hasil belajar siswa kembali meningkat, hal ini terlihat dari jumlah siswa yang tuntas sebanyak 18 orang siswa

\section{DAFTAR PUSTAKA}

Asnimar. (2018). Upaya Peningkatan Hasil Belajar Ilmu Pengetahuan Sosial dengan Pembelajaran Kooperatif Tipe TPS (Think Pair Share) Pada Kelas IV SD Negeri 001 Ukui Satu. Primary: Jurnal Pendidikan Guru Sekolah Dasar, 5(3), 113-119.

Gustomo, A., Sudarman. (2015). Penerapan Model Pembelajaran Snowball Throwing untuk Meningkatkan Hasil Belajar Siswa pada Kompetensi Memperbaiki Unit Kopling dan Komponen-Komponen Sistem Pengoperasian. Jurnal Pendidikan Teknik Mesin, 15(2), 59-63.

Intan, S., Suyuti.,\& Kapile, C. (2016). Meningkatkan Hasil Belajar Siswa pada Mata Pelajaran IPS dengan Menggunakan Metode Diskusi di Kelas IV SD Inpres Watunonju. Jurnal Kreatif Tadulako Online, 4(6), 102-126.

Istarani. (2012). 58 Model Pembelajaran Inovatif. Medan: Media Persada.

Komalasari, K. (2010). Pembelajaran Kontektual konsep dan aplikasi. Bandung: PT Reika Aditama.

Kurniyati, D. (2016). Peningkatan Hasil Belajar IPS dengan Menerapkan Model Pembelajaran Quantum Teaching di SD N Balong. Jurnal Pendidikan Guru Sekolah Dasar, 4(5), 324-333.

Lestari, W.D. (2014). Peningkatan Hasil Belajar IPS Melalui Model Pembelajaran Problem Based Lerning pada Siswa Kelas V SD atau $90 \%$ sedangkan siswa yang belum tuntas berkurang menjadi 2 orang siswa atau $10 \%$.

Berdasarkan simpulan penelitian di atas peneliti merekomendasikan sebagai berikut: 1) Model pembelajaran kooperatif tipe snowball throwing dapat dijadikan sebagai salah satu alternatif dalam pembelajaran IPS maupun mata pelajaran yang lainnya: 2) Bagi peneliti lanjutan, penelitian ini dapat dijadikan sebagai referensi untuk melakukan peneliti selanjutnya dengan tempat subjek yang berbeda.

Negeri Pojokrejo I Jombang. JPGSD, 02(03), 1-13.

Patimasang. (2015). Peningkatan Hasil Belajar IPS dengan Menggunakan Metode Kerja Kelompok Pada Siswa Kelas IV SDN Silampayang Patimasan. Jurnal Kreatif Tadulako Online, 2(4), 132-150.

Sagala, Syaiful. (2007). Konsep dan Makna Pembelajaran. Bandung: CV ALFABETA.

Suprijono, A. (2009). Cooperative Learning Teori \& Aplikasi PAIKEM. Yogyakarta: Pustaka Pelajar.

Sumarliani, A., \& Suprayitno. (2018). Penerapan Model Pembelajaran Kooperatif Tipe TPS (Think Pair Share) untuk Meningkatkan Hasil Belajar IPS pada Tema Indahnya Negeriku Siswa Kelas IV-A SDN Tanah Kalikedinding II/252 Surabaya. Jurnal Penelitian Pendidikan Guru Sekolah Dasar (JPGSD), 6(6), 859-869.

Trianto. 2007. Model-Model Pembelajaran Inovatif Berorientasi Konstruktivistik. Jakarta: Prestasi Pustaka Publisher.

Winataputra, dkk. (2012). Teori Belajar dan Pembelajaran. Jakarta: Universitas terbuka.

Yuliati. (2015). Efektifitas Penggunaan Model Kooperatif Tipe Snowball Throwing untuk Meningkatkan Hasil Belajar Siswa pada Materi Sistem Pertidaksamaan Linear di Kelas XI-IS-2 SMA Negeri 7 Banda Aceh. Jurnal Peluang, 3(2), 65-78 